\title{
EL KECHUA Y SU EXPANSION HACIA EL NORTE DEL IMPERIO INCAICO
}

(Suroeste del que fué Nuevo Reyno de Granada, hoy República de Colombia).

\author{
SERGIO ELIAS Ortiz
}

I. - La familia Kechua o Runa simi.

El nombre propio de ésta familia lingúística, atendiendo al testimonio de los mismos indígenas debería ser Runa Simi, que significa aproximadamente "lengua de la gente común". En documentos antiguos es llamada "Lengua General del Perú" o simplemente "Lengua General"; juntamente con estas .consideraciones se le dió el nombre de quichua reconocido oficialmente en el Concilio Provincial de Lima (1538). Este nombre fué introducido por el dominico Domingo de Santo Tomás en la gramática de esta lengua que publicara en Valladolid en 1560. Quichua era un pequeño Distrito del Perú Central situado en el valle del río Pachachaca. Este lugar no fué origen de los pueblos que hablan dicha lengua pues fué anexado por los Incas en sus conquistas.' El nombre quichua fué aceptado por otros gramáticos y se hizo de uso corriente.

El Inca Garcilaso le da el nombre de Cozco (Cuzco) por ser lengua palaciega y general, hablada en todo el Imperio durante los Incas. La voz Quichua es, sin embargo, la que ha perdurado, transformándose en quechua con varias grafías (Keshua, Quechua, Quechúa, etc.) habiendo sido adoptada en dicha forma por los lingüistas modernos.

La lengua kechua, como dice Rivet, fué la única que desempeñó en la América del Sur precolombina el papel de lengua de civilización, pues al hablarse en todo el Imperio era vínculo de unión entre los pue- 
blos sojuzgados y la metrópoli. Garcilaso afirma que los incas obligaban a los vencidos a aprender la lengua quichua y enviaban indios cuzqueños a enseñarla. Con todo, al llegar los españoles persistían lenguas naturales de las regiones conquistadas.

\section{II. - El Kechua lengua de relación para la conquista española.}

Verificada la Conquista y ante la dificultad de los indígenas de aprender el español, los misioneros convinieron en aprender el quichua y llevar adelante el método incaico de implantación. Así el quichua como lengua de evangelización llegó donde no había llegado con la influencia conquistadora de los incas y fueron extinguiéndose paulatinamente las lenguas autóctonas. A esto se agregó que los conquistadores trasladaban a gente de habla quechua a lugares donde no se hablaba la lengua, contribuyendo, por lo menos, a formar quechuismos que perduran hasta hoy.

\section{III. - Expansión del Kechua en el Suroeste del Nuevo Reyno de Grana- da, hoy República de Colombia.}

Debemos valernos de los factores de difusión del quichua que dejamos expuestos. Descartamos la posibilidad de que fuera introducido por los Incas, pues el Imperio sólo llegaba hasta el río Guaytará según los indicios de Mons. Lunardi. El quichua fué introducido a Colombia por los misioneros y encomenderos españoles. En el suroeste de Colombia había entonces tres lenguas en pleno vigor: la Pasto, la Killacinga y la Malla, todas dentro del actual Departamento de Nariño. De la Pasto y la Killacinga consta que se hablaban a fines del siglo XVI, pues el Obispo Fray Luis Lopez de Solís en 1593, ordenó la traducción del confesionario y del catecismo a esas lenguas. Esto demuestra que la introducción del quechua, llamada también Inga, no había tenido mucho éxito. También consta por otro documento que en 1635 todavía no se hablaba el inga en esas provincias.

Sin embargo, de la lucha, del quichua con las lenguas autóctonas, sobrevivió el quichua. De estas últimas sólo queda un dialecto en uso - el Koaiker-y algunos vocablos, generalmente patronímicos y toponímicos. En cambio el quichua persiste en algunos lugares y ha enriquecido el habla vulgar con muchos quechuismos.

\section{IV. - Estado actual del quichua en Colombia.}

La distribución es como sigue: Primero, en el Departamento de Nariño, la comunidad indígena de Aponte habla español y quichua (inga $y$ apontano); son ciento siete familias, con un total de quinientos sesenta individuos. Estos indígenas son a nuestro juicio de la misma extracción de los indígenas de habla quichua de Sibundoy. En el testamento del cacique de dicho valle en 1700 considera las tierras de Apon- 
te como propias de la tribu. Segundo, en el Departamento de Cauca quedan sólo dos familias de habla quichua en el municipio de Santa Rosa del Caquetá. En la comisaría de Caquetá y alrededores hablan quichua algunas pocas familias que no alcanzan a cincuenta individuos y que están en vías de desaparecer. Cuarto, en la Comisaría especial del Putumayo se habla el ingano (dialecto del quichua) en varios pueblos. En puerto Asis se habla otro dialecto del quichua, el napeño. El total de estos individuos parece elevarse a tres mil. Son bilingües, pues se hacen entender en español. En Colombia hablan el quichua y sus variedades unas cuatro mil personas, habiendo desaparecido núcleos importantes.

A la clasificación de la familia kechua hay que añadir pues, el núcleo colombiano con sus dialectos almaguero, aponteño, mocoano, ingano de el Andaqui, nombres locales de un mismo dialecto, pues todos descienden de la lengua inga introducida por los españoles. La prueba son muchas palabras quichuas conservadas iguales y con el mismo significado en todos estos dialectos.

El napeño procede del alto Napo y falta saber si llegó aquí por Maynas, Canelos o desde la Sierra Ecuatoriana. Entre el ingano y el napeño hay algunas notables diferencias tanto en léxico como en sintaxis, pero tales diferencias no dan lugar a una clasificación aparte.

Aunque no podemos saber con exactitud si el ingano de Colombia proviene del Perú o del Ecuador algunas razones nos permiten creer que proviene del quichua quiteño. Ellas son: 1.- Tradición constante entre los pueblos colombianos de habla quichua que atribuyen el origen de su lengua a agentes de Quito. 2.- Similitudes dialectales del ingano con el dialecto de los indígenas ecuatorianos de la sierra andina. 3.- La existencia de voces extrañas de posible origen quiteño.

El Sr. Joaquín Richa hizo un breve estudio de las diferencias del ingano con el quichua. Llegó a la conclusión que casi todas las palabras quichuas han cambiado en cuanto a pronunciación. Los sonidos fuertes del quichua se han suavizado, se han perdido las aspiraciones, los sonidos palatales se han transformado en aspirados y los suaves han pasado a ser fuertes.

Muchas voces del inga se han perdido, siendo reemplazadas por vocablos castellanos. Sin embargo, el cambio ha sido tan insignificante que persona de habla quichua del Perú pudo entenderse con los inganos de Sibundoy y estos con los indígenas ecuatorianos de la sierra.

Réstanos hablar de la influencia del quichua sobre las demás lenguas. La que más ha sufrido esta influencia es el español, no sólo en la asimilación de quechuismos, sino en la formación de palabras mixtas (español o quichua y viceversa). El quichua ha influído también, a veces muy poderosamente, en las demás familias lingüísticas americanas.

Sobre el posible origen de la lengua quichua resaltamos la opinión del Dr. Ferrario, de la Universidad de Montevideo. Anota el aisla- 
miento del quichua y del aimara con los demás idiomas americanos tanto en léxico, morfología y sintaxis. Investiga luego la posibilidad de un parentesco remoto del quichua con la familia "Altaica" mediante raices, correspondencias fonéticas, etc., y deja en el ánimo del lector, no ya la posibilidad, sino la certeza de una procedencia asiática del pueblo quichua.

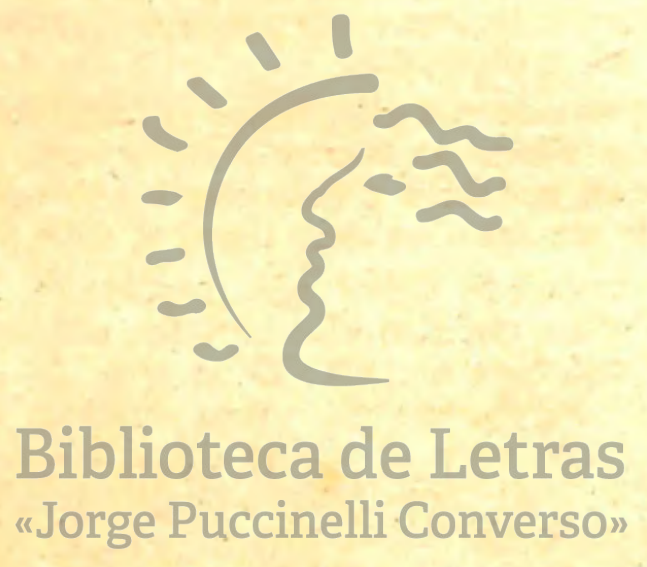

